\title{
Algoritma Dijkstra untuk Menentukan Jalur Tercepat pada Pendistribusian Barang Berbasis Mobile
}

\author{
Rumini $^{\# 1}$, Dian Lesmana ${ }^{\# 2}$

 \\ Jl. Ring Road Utara, Condong Catur, Depok, Sleman, Yogyakarta, 55283 \\ ${ }^{1}$ ruminieamikom.ac.id \\ 2dian. lesmana@students.amikom.ac.id
}

\begin{abstract}
Abstrak
Seiring dengan banyaknya perkembangan teknologi, perkembangan smartphone berkembang sangat pesat. Saat ini smartphone telah menjadi perangkat yang banyak dimiliki oleh semua kalangan masyarakat, dari kelas menengah kebawah sampai menengah keatas. Salah satu sistem operasi yang digunakan pada smartphone adalah mobile, pada sistem operasi mobile tersebut banyak menyediakan berbagai macam aplikasi, salah satunya adalah aplikasi yang memanfaatkan fungsi dari lokasi dengan menggunakan GPS (Global Positioning System). Global Positioning System (GPS) adalah sistem navigasi berbasis satelit yang dapat digunakan untuk menginformasikan lokasi, kecepatan, arah, dan waktu. Sistem GPS tersebut dapat dimanfaatkan untuk mendapatkan lokasi toko yang akan didistribusi secara cepat dan mudah. Penelitian ini dalam menentukan jalur terpendek dapat diselesaikan dengan permodelan graf menggunakan algoritma dijkstra. Metodologi peneltiian diantaranya mengumpulkan data, analisis kebutuhan, perancangan, implementasi dan pengujian. Algoritma dijkstra menggunakan prinsip greedy, yaitu mencari jalur terpendek dari satu titik ke titik lainnya yang terhubung. Algoritma dijkstra ini diterapkan pada sebuah aplikasi location based service dengan platform mobile yang memanfaatkan Google Map sebagai petanya. Tujuan dari penelitian ini adalah untuk menghasilkan suatu aplikasi Location Based Service (LBS) pada perangkat mobile berbasis Mobile, yang mampu membantu menentukan jalur tercepat untuk pendistribusian barang agar dapat mengefisiensi waktu dan biaya sekaligus dapat memberikan masukan untuk google bahwa dalam aplikasi ini dapat menentukan lebih dari satu tujuan di dalam maps dalam sekali jalan, sehingga dapat diketahui jalur terpendek yang akan dituju terlebih dahulu, sedangkan google maps hanya dapat menentukan satu tujuan dalam perjalanan. Aplikasi dapat menunjukkan jalur pendistribusian barang lebih dari satu tujuan. Aplikasi dapat memberikan informasi urutan toko menurut jarak terdekat sesuai tujuan yang telah dipilih. Berdasarkan hasil pengujian jarak yang telah dilakukan, diketahui bahwa persentase rata-rata selisih jarak antara algoritma Djikstra dengan metode haversine sebesar $0.648 \%$. Sehingga dapat disimpulkan bahwa aplikasi distribusi ini dapat menghitung jarak dengan cukup baik.
\end{abstract}

\section{Dijkstra's Algorithm for Determining the Fastest Path for Mobile-Based Goods Distribution}

\begin{abstract}
Along with the many technological developments, the development of smartphones is growing very rapidly. Currently, smartphones have become devices that are widely owned by all people, from the lower middle class to the upper-middle class. One of the operating systems used on smartphones is mobile, the mobile operating system provides various kinds of applications, one of which is an application that utilizes the function of the location using GPS (Global Positioning System). The Global Positioning System (GPS) is a satellite-based navigation system that can be used to inform location, speed, direction, and time. The GPS can be used to quickly and easily locate the stores to be distributed. This research in determining the shortest path can be solved by graph modeling using the Dijkstra algorithm. The research methodology includes data collection, needs analysis, design, implementation, and testing. The Dijkstra algorithm uses the greedy principle, which is to find the shortest path from one connecting point to another. The JKTRA algorithm is applied to a location-based service application with a mobile platform that uses Google Map as the map. The purpose of this research is to produce a Location-Based Service (LBS) application on a Mobile-based mobile device, which can help determine the fastest route for the distribution of goods to save time and costs as well as provide input to Google that in this
\end{abstract}


application it can determine more than one destination on maps at a time, so you can find the shortest path to go first, while google maps can only determine one destination on the way. The application can show the distribution route of goods from more than one destination. Applications can provide information on the order of stores according to the closest distance according to the destination that has been selected. Based on the results of the distance test that has been carried out, it is known that the average percentage difference between the Djiktra algorithm with haversine method is $0.648 \%$. So it can be concluded that this distribution application can calculate the distance quite well.

Keywords: Location Based Service, Distribution of goods, Dijkstra's Algorithm, Android, Distance, Mobile App

\section{Pendahuluan}

Seiring dengan banyaknya perkembangan teknologi, perkembangan smartphone juga berkembang sangat pesat. Kini smartphone telah menjadi perangkat yang banyak dimiliki oleh semua kalangan masyarakat, dari kelas menengah kebawah sampai menengah keatas, harga dari smartphone sangatlah bervariasi dari harga ratusan ribu sampai puluhan juta, sesuai dengan fitur yang di sediakan oleh smartphone tersebut. Salah satu sistem operasi yang digunakan pada smartphone adalah mobile, pada sistem operasi mobile tersebut banyak menyediakan berbagai macam aplikasi, salah satunya adalah aplikasi yang memanfaatkan fungsi dari lokasi dengan menggunakan GPS (Global Positioning System) [1].

Global Positioning System (GPS) adalah sistem navigasi berbasis satelit yang dapat digunakan untuk menginformasikan lokasi, kecepatan, arah, dan waktu. Sistem GPS tersebut dapat dimanfaatkan untuk mendapatkan lokasi toko yang akan didistribusi secara cepat dan mudah, sedangkan untuk penentuan jalur menggunakan algoritma Dijksta. Algoritma Dijkstra merupakan salah satu algoritma yang paling sering digunakan dalam pencarian rute terpendek, karena algoritma Dijkstra menggunakan graf berarah untuk penentuan jalur terpendek. Menurut penemunya, Edsger Dijkstra. Algoritma Dijkstra menggunakan prinsip greedy, yaitu mencari jalur terpendek dari satu titik ke titik lainnya yang terhubung. Prinsip dari algoritma Dijkstra hampir sama dengan BFS (Breadth Frist Search) dengan antrian priority queue, jadi hanya simpul prioritas tertinggi yang ditelusuri. Algoritma Dijkstra ini membandingkan dari simpul pada satu level, dan akan dibandingkan lagi rute yang baru.

Berdasarkan latar belakang permasalahan, rumusan masalah pada penelitian ini adalah Bagaimana pengimplementasian algoritma Dijkstra dalam menentukan jalur terpendek untuk pendistribusian barang pada aplikasi android.

Berdasarkan uraian diatas, maka penelitian ini bertujuan untuk membuat aplikasi yang diharapkan dapat membantu para pemasok barang maupun reseller dalam menentukan jalur tercepat untuk pendistribusian barang yang pengirimanya lebih dari satu tujuan, dengan memanfaatkan fitur GPS yang di sediakan pada smartphone mobile dan menggunakan algoritma Dijkstra sebagai penentuan jalur terpendek.

Penelitian ini dapat memasukkan data pada banyaknya tujuan, seperti memberikan informasi urutan tujuan menurut jarak terdekat sesuai beberapa tujuan yang telah dipilih, sehingga user dapat diberikan keputusan jalur mana yang dapat ditempuh terlebih dahulu. Perhatikan google maps application yang dapat memasukkan satu tujuan dalam aplikasinya bukan di lebih dari satu tujuan.

\section{Metodologi}

Metodologi penelitian merupakan suatu perencanaan penelitian yang akan dilakukan secara sistematis dan ilmiah. Proses tersebut dilakukan dengan mendesain perencanaan penelitian sesuai dengan tahapan yang dilakukan pada penelitian. Metodologi penelitian tersebut diilustrasikan pada Gambar 1.

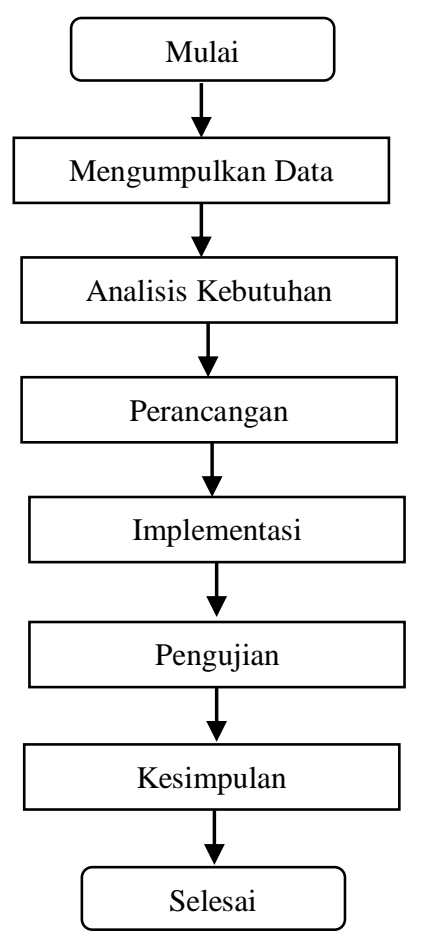

Gambar 1. Metodologi penelitian

\section{A. Pengumpulan Data}

Metode pengamatan merupakan pendekatan untuk melaksanakan pengamatan secara langung tentang distribusi barang suatu pemasok untuk mendapatkan seluruh aspek yang dibutuhkan dalam pembuatan aplikasi dalam menentukan masalah yang ada. Survei akan dilakukan untuk pengumpulan data agar data yang dimuat lebih akurat.

\section{B. Analisis Kebutuhan}

Data distibusi barang memuat data titik koordinat lokasi distribusi barang. Untuk menampilkan data navigasi distribusi barang, maka diperlukan metode Location Based Service untuk mendeteksi lokasi. Location Based Services adalah layanan berbasis lokasi untuk menggambarkan teknologi yang digunakan untuk 
menemukan lokasi perangkat yang pengguna gunakan. Layanan ini menggunakan teknologi global positioning system (GPS) dan cell-based location yang didapatkan dari operator penyedia jaringan pada perangkat. GPS adalah singkatan dari Global Positioning System, yang merupakan sistem navigasi dengan menggunakan teknologi satelit yang dapat menerima sinyal dari satelit [2]. GPS bekerja dengan menghubungkan sinyal satelit ke perangkat GPS itu sendiri yang selanjutnya Informasi dari GPS itu akan di transmisikan oleh beberapa satelit sehingga GPS receiver mampu untuk mengetahui dan menentukan seakurat mungkin dimana posisi pengguna fitur GPS [3]. Perangkat GPS akan menangkap sinyal NMEA dari satelit GPS yang menghasilkan koordinat latitute dan longitude terhadap lokasi perangkat GPS tersebut berada [4]. Aplikasi mobile ini untuk pendistribusian barang yang pengirimanya lebih dari satu tujuan, dengan memanfaatkan fitur GPS yang di sediakan pada smartphone mobile dan menggunakan algoritma Dijkstra sebagai penentuan jalur terpende

C. Perancangan Use Case Diagram

Di bawah ini merupakan Use Case Diagram yang digunakan untuk membantu membuat aplikasi distribusi barang. bisa di lihat di Gambar 2 Use Case Diagram:

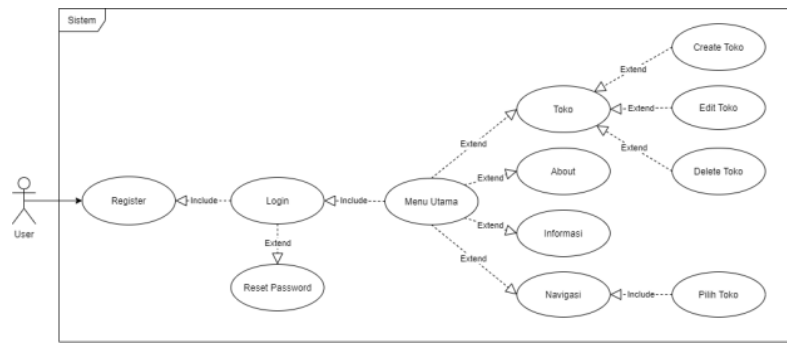

Gambar 2. Use case diagram

\section{Implementasi}

Sistem yang dibuat akan diimplementasikan menjadi sebuah aplikasi berbasis mobile yang terhubung dengan koneksi internet. Internet digunakan untuk mengambil data dan penentuan lokasi. Segala proses akan dilakukan di perangkat pengguna, seperti pengolahan data dan penentuan informasi yang diberikan.

\section{E. Pengujian}

Pengujian sistem merupakan hal yang penting dari tahapan pembangunan sistem. Tahap pengujian bertujuan untuk menemukan masalah-masalah atau kesalahan yang mungkin terjadi pada aplikasi yang telah dibangun. Pengujian ini bermanfaat untuk mengetahui apakah aplikasi telah sesuai dengan kriteria kebutuhan sistem yang dibangun dan tujuan perancangannya.

\section{F. Kesimpulan}

Penarikan kesimpulan dirumuskan berdasarkan analisis hasil pengujian dan mengacu pada tujuan dari penelitian yang dilakukan. Dari penelitian yang telah dilakukan didapatkan sebuah pengetahuan baru yang dapat dijadikan sebagai bahan penelitian selanjutnya.

\section{HASIL DAN PEMBAHASAN}

\section{A. Implementasi}

Halaman ini merupakan halaman awal dari aplikasi. Di dalam halaman menu utama ini terdapat lima sub menu yaitu toko, navigasi, informasi, tentang, dan logout. Gambar halaman menu utama bisa dilihat pada Gambar 3.

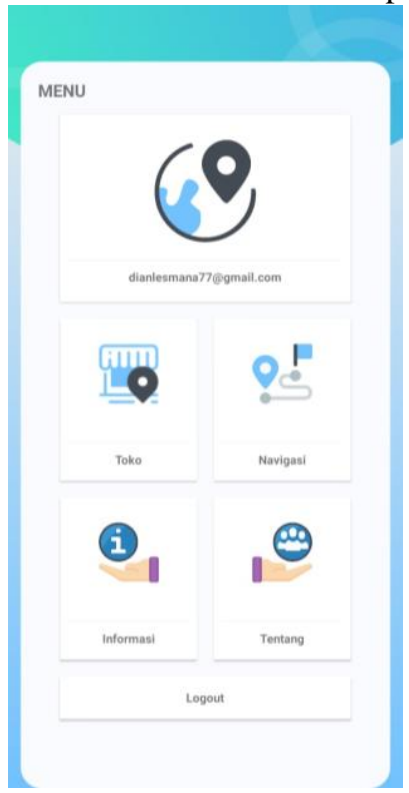

Gambar 3. Menu utama

1) Halaman menu toko: Halaman ini merupakan halaman untuk mengelola toko yang tersimpan di aplikasi berdasarkan user yang login, toko yang ada di dalam menu toko tersimpan di firebase realtime database jadi data yang ada di menu toko bersifat realtime dan online bisa di akses dimanapun asal terkoneksi dengan internet dan login sesuai akun yang telah terdaftar. di menu toko juga terdapat fungsi menambah toko, mengedit toko dan menghapus toko. Gambar halaman toko dapat dilihat pada Gambar 4.

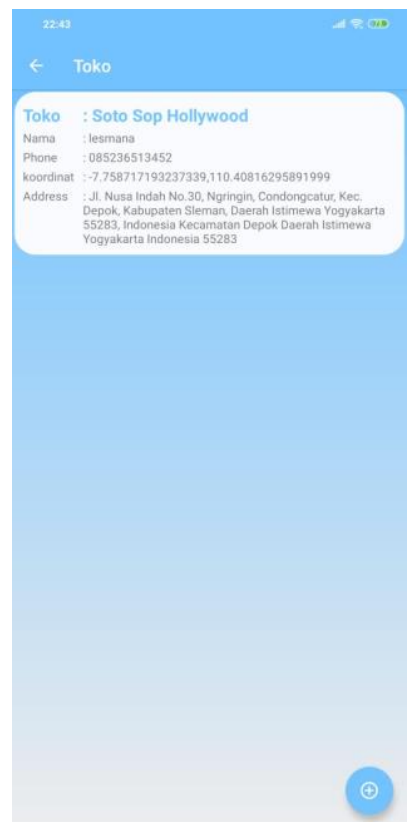

Gambar 4. Halaman menu toko 
2) Halaman peta pemilihan lokasi took: Halaman ini merupakan halaman pemilihan lokasi toko yang akan di simpan. Gambar Peta memilih lokasi toko bisa di lihat pada Gambar 5.

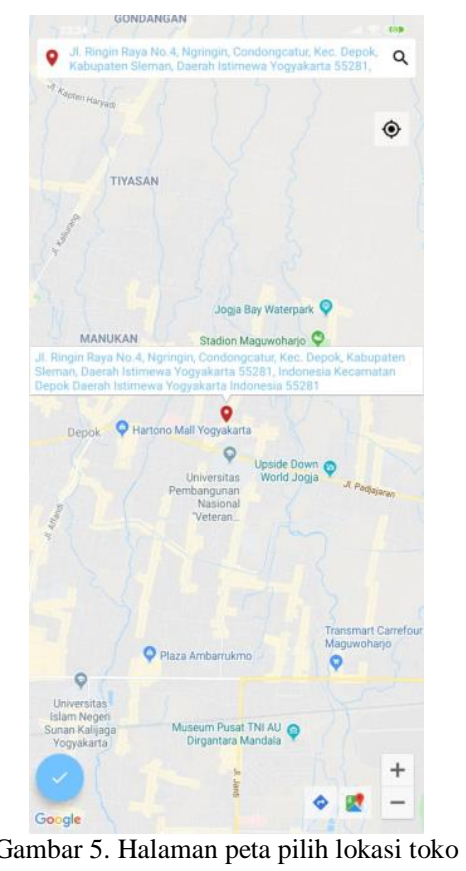

3) Halaman menu navigasi: Di halaman ini user diminta untuk memilih toko yang akan dicari jalur terpendek nya dengan cara mencentang kotak yang ada di sebelah kanan, lalu jika sudah terpilih semua user diminta menekan tombol navigasi yang ada di paling bawah. Gambar halaman navigasi toko dapat dilihat pada Gambar 6.

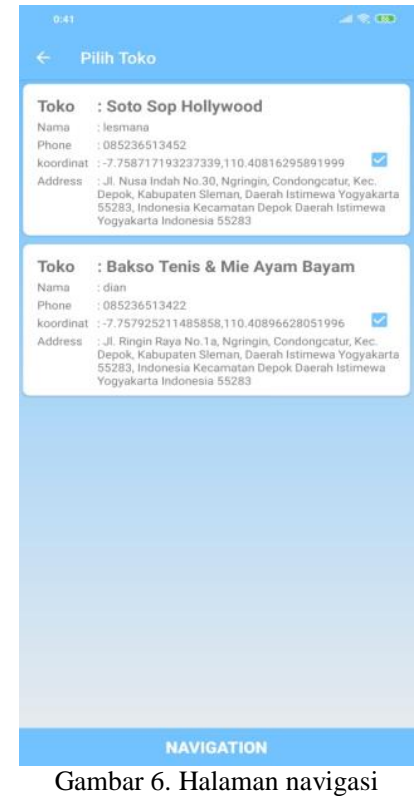

4) Halaman peta: Halaman ini berfungsi untuk menampilkan jalur terpendak sesuai tujuan yang sudah di pilih di menu navigasi. Gambar halaman peta dapat dilihat pada Gambar 7.

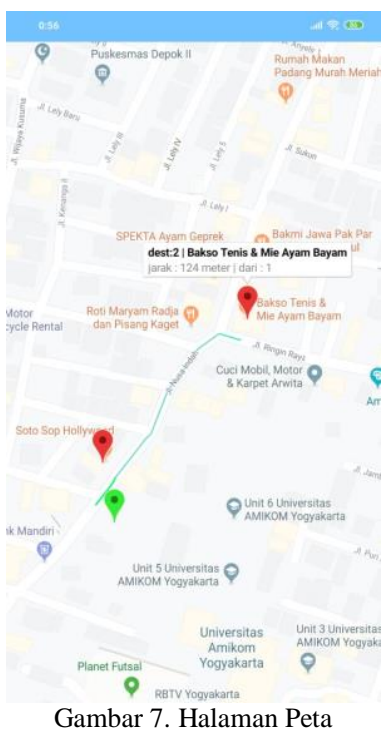

\section{B. Pengujian Aplikasi (algoritma Djikstra dengan Haversine)}

1) Pengujian jarak aplikasi distribusi barang: Pengujian jarak antara aplikasi distribusi barang dengan formula haversine. Formula Haversine adalah persamaan yang digunakan dalam navigasi, yang memberikan jarak lingkaran besar antara dua titik pada permukaan bola (bumi) berdasarkan bujur dan lintang. Formula Haversine merupakan suatu metode untuk mengetahui jarak antar dua titik dengan memperhitungkan bahwa bumi bukanlah sebuah bidang datar namun adalah sebuah bidang yang memilki derajat kelengkungan. Penggunaan rumus ini mengasumsikan pengabaian efek ellipsoidal, ketinggian bukit dan kedalaman lembah di permukaan bumi. Berikut adalah rumus haversine:

$$
\begin{aligned}
\Delta \widehat{\sigma}=2 \operatorname{rarsin}\left(\sqrt{\sin ^{2}\left(\frac{\Delta \emptyset}{2}\right)+\cos \emptyset_{s} \cos \emptyset_{f} \sin ^{2}\left(\frac{\Delta \lambda}{2}\right)}\right) \\
\Delta \sigma=\text { Interior Spherical Angle } \\
\Delta \phi=\text { Latitude1-latitude2 } \\
\phi_{s}=\text { Latitude1 } \\
\phi_{f}=\text { Latitude2 } \\
\Delta \lambda=\text { Longitude1-longitude2 }
\end{aligned}
$$

Tabel pengujian jarak antara aplikasi yang dibuat dengan algoritma djikstra dengan metode haversin, dapat dilihat pada Tabel I.

Tabel perhitungan jarak antara aplikasi yang dibuat dengan algoritma djikstra dengan metode haversin, dapat dilihat pada Tabel II. 
TABEL I

PENGUJIAN JARAK

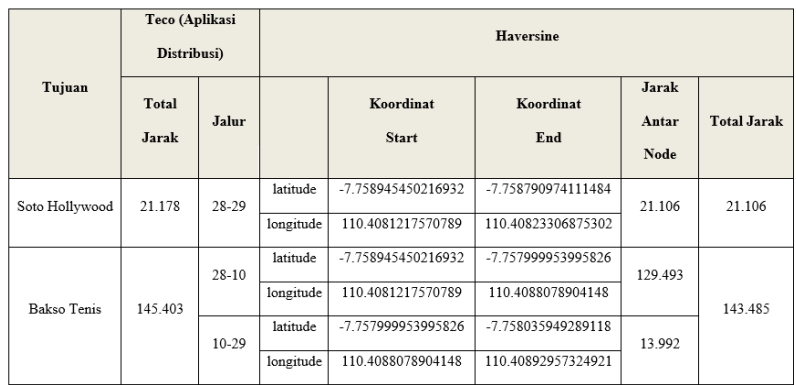

TABEL II

PERHITUNGAN JARAK

\begin{tabular}{|l|l|c|c|c|c|}
\hline \multirow{2}{*}{ No } & \multirow{2}{*}{ Tujuan } & $\begin{array}{c}\text { Teco (Aplikasi } \\
\text { distribusi }\end{array}$ & $\begin{array}{c}\text { Perhitungan } \\
\text { Haversine }\end{array}$ & $\begin{array}{c}\text { Selisih } \\
\text { jarak } \\
\text { (meter) }\end{array}$ & $\begin{array}{c}\text { Persentase } \\
\text { perbedaan } \\
\text { jarak }\end{array}$ \\
\cline { 3 - 5 } 1 & $\begin{array}{l}\text { Soto Sop } \\
\text { Hollywood }\end{array}$ & 21.178 & 21.106 & 0.072 & 0.341 \\
\hline 2 & Bakso Tenis & 145.403 & 143.485 & 1.918 & 1.337 \\
\hline 3 & $\begin{array}{l}\text { Ayam Goreng } \\
\text { Sumami 2 }\end{array}$ & 336.725 & 333.897 & 2.828 & 0.847 \\
\hline 4 & Lesehan Za'nur & 471.191 & 468.780 & 2.411 & 0.514 \\
\hline 5 & $\begin{array}{l}\text { Warmindo } \\
\text { Geulis }\end{array}$ & 898.483 & 894.031 & 4.452 & 0.498 \\
\hline 6 & Padang Murah & 749.714 & 747.545 & 2.169 & 0.290 \\
\hline 7 & $\begin{array}{l}\text { Warung Makan } \\
\text { Lely }\end{array}$ & 267.878 & 265.646 & 2.232 & 0.840 \\
\hline 8 & Mas Kobis & 719.893 & 715.386 & 4.507 & 0.630 \\
\hline 9 & $\begin{array}{l}\text { Warung Makan } \\
\text { Larisa }\end{array}$ & 596.413 & 594.933 & 1.48 & 0.249 \\
\hline
\end{tabular}

2) Pengujian Blackbox: BlackBox Testing adalah cara pengujian dilakukan oleh user (pengguna)/klien dengan cara menjalankan atau mengeksekusi suatu aplikasi/program melalui diamati apakah hasil dari aplikasi sesuai dengan proses dan hasil yang diinginkan. Metode pengujian ini melihat apakah hasil akhir (output) dari proses perangkat lunak yang dibangun sesuai dengan rancangan awal pembuatan aplikasi, baik dari segi fungsionalitas maupun struktur internal [5].

\section{a. Halaman Daftar Akun}

Tabel pengujian halaman daftar akun dapat dilihat pada Tabel III.

TABEL III

PENGUJIAN HALAMAN DAFTAR AKUN

\begin{tabular}{|l|l|l|}
\hline $\begin{array}{l}\text { Metode } \\
\text { penggujian }\end{array}$ & $\begin{array}{l}\text { User daftar dengan akun yang belum } \\
\text { terdaftar } \\
\text { 2. } \begin{array}{l}\text { User daftar dengan akun yang sudah } \\
\text { terdaftar }\end{array}\end{array}$ \\
\hline $\begin{array}{l}\text { Hasil } \\
\text { pengujian }\end{array}$ & \begin{tabular}{l} 
3. $\begin{array}{l}\text { Register menampilkan Toast berhasil } \\
\text { terdaftar } \\
\text { Register menampilkan Toast email sudah } \\
\text { terdaftar }\end{array}$ \\
\hline Kesimpulan
\end{tabular} Sukses \\
\hline
\end{tabular}

b. Halaman Login

Tabel pengujian halaman login akun dapat dilihat pada Tabel IV.
TABEL IV

PENGujian Halaman Login

\begin{tabular}{|l|l|}
\hline $\begin{array}{l}\text { Metode } \\
\text { penggujian }\end{array}$ & $\begin{array}{l}\text { 1. User login dengan akun yang sudah terdaftar } \\
\text { 2. User login dengan akun yang belum terdaftar }\end{array}$ \\
\hline $\begin{array}{l}\text { Hasil } \\
\text { pengujian }\end{array}$ & $\begin{array}{l}\text { 3. Login menampilkan Toast berhasil login dan } \\
\text { masuk ke menu utama } \\
\text { 4. Login menampilkan Toast email atau } \\
\text { password salah }\end{array}$ \\
\hline Kesimpulan & Sukses \\
\hline
\end{tabular}

c. Halaman Lupa Password

Tabel pengujian halaman lupa password akun dapat dilihat pada Tabel V

TABEL V

PENGUJiAn HALAMAN LUPA PASSWORD AKUN

\begin{tabular}{|l|l|}
\hline $\begin{array}{l}\text { Metode } \\
\text { penggujian }\end{array}$ & $\begin{array}{l}\text { 1. User menginputkan dengan akun yang sudah } \\
\text { terdaftar } \\
\text { 2. User menginputkan dengan akun yang belum } \\
\text { terdaftar }\end{array}$ \\
\hline $\begin{array}{l}\text { Hasil } \\
\text { pengujian }\end{array}$ & $\begin{array}{l}\text { 1. Lupa password menampilkan toast mengirim } \\
\text { email reset password. } \\
\text { 2. Lupa password menampilkan toast gagal } \\
\text { mengirim email reset password. }\end{array}$ \\
\hline Kesimpulan & Sukses \\
\hline
\end{tabular}

d. Menu Utama

Tabel pengujian menu utama dapat dilihat pada Tabel VI.

TABEL VI

Pengujian Halaman Menu Utama

\begin{tabular}{|l|l|}
\hline $\begin{array}{l}\text { Metode } \\
\text { penggujian }\end{array}$ & $\begin{array}{l}\text { User menekan tombol, Toko, Navigasi, } \\
\text { Informasi, Tentang, dan Logout }\end{array}$ \\
\hline $\begin{array}{l}\text { Hasil } \\
\text { pengujian }\end{array}$ & $\begin{array}{l}\text { Menu utama berhasil berpindah ke halaman } \\
\text { Toko, Navigasi, Informasi, Tentang, dan } \\
\text { Logout. }\end{array}$ \\
\hline Kesimpulan & Sukses \\
\hline
\end{tabular}

e. Menu Toko

Tabel pengujian menu toko dapat dilihat pada Tabel VII.

TABEL VII

Pengujian Hal aman Menu Toko

\begin{tabular}{|l|l|}
\hline Metode & 3. User masuk ke menu toko \\
penggujian & $\begin{array}{l}\text { 4. User menekan tombol tambah toko } \\
\text { 5. User menekan lama pada salah satu toko yang } \\
\text { ada di menu toko } \\
\text { 6. User menekan Ubah Toko } \\
\text { 7. User menekan Delete toko }\end{array}$ \\
\hline $\begin{array}{l}\text { Hasil } \\
\text { pengujian }\end{array}$ & $\begin{array}{l}\text { 1. Menu toko Berhasil menampilkan daftar toko } \\
\text { yang sudah di inputkan sebelumnya sesuai akun } \\
\text { yang login }\end{array}$ \\
& $\begin{array}{l}\text { 2. Menu toko berhasil berpindah ke halaman } \\
\text { tambah toko. }\end{array}$ \\
& $\begin{array}{l}\text { 3. Menu toko berhasil menampilkan dialog } \\
\text { peringatan untuk mengubah atau menghapus } \\
\text { toko. Menu toko berhasil berpindah ke halaman ubah } \\
\text { toko }\end{array}$ \\
\hline Kesimpulan & Sukses \\
\hline
\end{tabular}

f. Halaman Tambah Toko

Tabel pengujian halaman tambah toko dapat dilihat pada Tabel VIII.

g. Halaman Peta Pilih Lokasi Toko

Tabel pengujian halaman peta pilih lokasi toko dapat dilihat pada Tabel IX. 
TABEL VIII

PENGUJian Halaman NAMBAH TOKO

\begin{tabular}{|l|l|}
\hline Metode \\
penggujian & $\begin{array}{l}\text { 1. User menginputkan detail toko } \\
\text { 2. User menekan tombol maps } \\
\text { 3. User menekan simpan }\end{array}$ \\
\hline $\begin{array}{l}\text { Hasil } \\
\text { pengujian }\end{array}$ & $\begin{array}{l}\text { 1. Halaman tambah toko berhasil meninputkan } \\
\text { detail toko } \\
\text { 2. Halaman tambah toko berhasil berpindah ke } \\
\text { halaman peta pilih lokasi toko } \\
\text { 3. Halaman tambah toko berhasil menyipan toko, } \\
\text { dan menampilkanya di menu toko }\end{array}$ \\
\hline Kesimpulan & \begin{tabular}{l} 
Sukses \\
\hline
\end{tabular} \\
\hline
\end{tabular}

TABEL IX

PENGUJian HALAMAN PeTA

\begin{tabular}{|l|l|}
\hline $\begin{array}{l}\text { Metode } \\
\text { penggujian }\end{array}$ & $\begin{array}{l}\text { 1. User memilih toko yang ada di peta. } \\
\text { 2. User mencari di pencarian toko } \\
\text { 3. User menyimpan alamat dan koordinat toko }\end{array}$ \\
\hline $\begin{array}{l}\text { Hasil } \\
\text { pengujian }\end{array}$ & $\begin{array}{l}\text { 1. Halaman peta pilih lokasi toko dapat } \\
\text { menunjukkan alamat toko sesuai yang dipilih }\end{array}$ \\
$\begin{array}{l}\text { 2. Halaman peta pilih lokasi toko dapat } \\
\text { menampilkan hasil pencarian toko }\end{array}$ \\
$\begin{array}{l}\text { 3. Halaman peta pilih lokasi toko dapat } \\
\text { menyimpan alamat dan koordinat toko dan di } \\
\text { masukkan ke halaman tambah toko }\end{array}$ \\
\hline Kesimpulan & Sukses \\
\hline
\end{tabular}

h. Halaman Ubah Toko

Tabel pengujian halaman ubah toko dapat dilihat pada Tabel X.

TABEL $X$

PENGUJiAn HALAMAN UBAH TOKO

\begin{tabular}{|l|l|}
\hline $\begin{array}{l}\text { Metode } \\
\text { penggujian }\end{array}$ & $\begin{array}{l}\text { 1. User masuk halaman ubah toko } \\
\text { 2. User mengubah detail toko } \\
\text { 3. User menekan tombol simpan }\end{array}$ \\
\hline $\begin{array}{l}\text { Hasil } \\
\text { pengujian }\end{array}$ & $\begin{array}{l}\text { 1. Halaman ubah toko berhasil menampilkan detail } \\
\text { toko yang dipilih. }\end{array}$ \\
& $\begin{array}{l}\text { 2. Halaman ubah toko dapat di ubah detail toko. } \\
\text { 3. Halaman ubah toko dapat menyimpan hasil data } \\
\text { yang di ubah dan menampilkanya di menu toko. }\end{array}$ \\
\hline Kesimpulan & Sukses \\
\hline
\end{tabular}

\section{i. Menu Navigasi} $\mathrm{XI}$

Tabel pengujian menu navigasi dapat dilihat pada Tabel

TABEL XI

PENGUJIAN HALAMAN NAVIGASI

\begin{tabular}{|c|c|}
\hline $\begin{array}{l}\text { Metode } \\
\text { penggujian }\end{array}$ & $\begin{array}{l}\text { 1. User masuk ke menu navigasi. } \\
\text { 2. User memilih toko yang akan jadi tujuan, } \\
\text { 3. User menekan tombol navigasi }\end{array}$ \\
\hline $\begin{array}{l}\text { Hasil } \\
\text { pengujian }\end{array}$ & $\begin{array}{l}\text { 1. Menu navigasi dapat menampilkan toko yang } \\
\text { sudah dibuat di menu toko. } \\
\text { 2. Menu navigasi dapat memilih toko tujuan, dan } \\
\text { bisa lebih dari satu } \\
\text { 3. Menu navigasi berhasil memindahkan data toko } \\
\text { yang di pilih ke halaman peta untuk dihitung } \\
\text { dan dicari jalan terpendeknya. }\end{array}$ \\
\hline Kesimpulan & Sukses \\
\hline
\end{tabular}

\section{j. Halaman Peta Navigasi}

Tabel Pengujian halaman peta navigasi dapat dilihat pada Tabel XII.

k. Halaman Informasi

Tabel pengujian halaman informasi dapat dilihat pada Tabel XIII.

1. Halaman Tentang

Tabel pengujian halaman tentang dapat dilihat pada Tabel XIV.
TABEL XII

PENGUJian Halaman Peta NaVigasi

\begin{tabular}{|l|l|}
\hline $\begin{array}{l}\text { Metode } \\
\text { penggujian }\end{array}$ & $\begin{array}{l}\text { 1. User masuk ke halaman navigasi dari menu } \\
\text { navigasi } \\
\text { 2. User menekan pin yang ada di peta. }\end{array}$ \\
\hline Hasil pengujian & $\begin{array}{l}\text { 4. Halaman peta navigasi dapat menampilkan rute } \\
\text { terdekat. } \\
\text { 5. Halaman peta navigasi dapat menampilkan } \\
\text { keterangan, toko, jarak, dan urutan tujuan. }\end{array}$ \\
\hline Kesimpulan & Sukses \\
\hline
\end{tabular}

TABEL XIII

PENGUJIAN HALAMAN INFORMASI

\begin{tabular}{|l|l|}
\hline $\begin{array}{l}\text { Metode } \\
\text { penggujian }\end{array}$ & User masuk ke dalam menu informasi \\
\hline $\begin{array}{l}\text { Hasil } \\
\text { pengujian }\end{array}$ & $\begin{array}{l}\text { Berhasil masuk ke dalam halaman informasi dan } \\
\text { berhasil menampilkan informasi penggunaan } \\
\text { aplikasi }\end{array}$ \\
\hline Kesimpulan & Sukses \\
\hline
\end{tabular}

TABEL XIV.

PENGUJian Halaman TENTANG

\begin{tabular}{|l|l|}
\hline Metode penggujian & User masuk ke halaman Tentang \\
\hline Hasil pengujian & Halaman tentang dapat tampilkan. \\
\hline Kesimpulan & Sukses \\
\hline
\end{tabular}

Dari pengujian yang telah dilakukan, adapun hasil analisis yang didapat dari aplikasi distibusi barang adalah sebagai berikut:

1. Aplikasi dapat mendeteksi maps/navigasi yang telah di gambarkan dengan titik yang ada di google maps

2. Aplikasi dapat menunjukkan peta tempat tujuan secara berurutan dari yang telah diinputkan

3. Aplikasi yang dibangun tidak memerlukan perangkat tambahan seperti sensor, mikrokontroler, dll. Cukup menggunakan jaringan internet yang umumnya sudah tersedia di perangkat smartphone.

4. Sistem menyediakan fitur khusus yang digunakan oleh admin untuk pengelolaan data toko.

5. Berdasarkan hasil pengujian jarak yang telah dilakukan, diketahui bahwa persentase rata-rata selisih jarak antara aplikasi yang dibuat (menggunakan algoritma Djikstra) dan haversine sebesar $0.648 \%$. Sehingga dapat disimpulkan bahwa aplikasi distribusi barang dapat menghitung jarak dengan cukup baik.

\section{KESIMPULAN}

Setelah dilakukan pengujian dan analisa aplikasi yang telah dibuat, dapat disimpulkan bahwa aplikasi pencarian jalur terpendek untuk pendistribusian barang berbasis mobile, dimana aplikasi ini dapat melakukan pencarian jalur pendek berdasarkan tujuan yang telah di tentukan oleh pengguna menggunakan algoritma Dijkstra. Aplikasi dapat menunjukkan jalur pendistribusian barang lebih dari satu tujuan dan dapat memberikan informasi urutan toko menurut jarak terdekat sesuai tujuan yang telah dipilih. Berdasarkan pengujian aplikasi pada beberapa perangkat, Aplikasi dapat dipasang dan menjalankan fitur-fitur 
dengan baik pada perangkat mobile pada sistem operasi android dengan minimum versi Android 5.0. Fitur-fitur tersebut meliputi fitur toko, navigasi, informasi dan tentang aplikasi distribusi barang ini. Dan untuk hasil pengujian jarak yang telah dilakukan, diketahui bahwa persentase rata-rata selisih jarak antara aplikasi yang dibuat (menggunakan algoritma Djikstra) dan haversine sebesar $0.648 \%$. Sehingga dapat disimpulkan bahwa aplikasi distribusi barang dapat menghitung jarak dengan cukup baik.

\section{DAFTAR PUSTAKA}

[1] M.R, "GPS (Global Positioning System)." https://www.kajianpustaka.com/2017/09/gps-globalpositioning-system.html.

[2] A. S. and D. R.E.C., "Implementasi Global Positioning System (GPS) dan Location Based Service (LBS) pada Sistem Informasi Kereta Api untuk Wilayah Jabodetabek," $J$. SISFOTEK Glob., vol. 7, pp. 27-33, 2017.

[3] N. Rachmat, A. Muhajirin, and Muchsin, "Tracking Kendaraan Mobil Dengan Pemanfaatan GPS Berbasis Android," J. Kaji. Ilm. UBJ, vol. 15, pp. 103-120, 2015.

[4] M. R. Fahlivi and Attariq, "Sistem Tracking Position Berdasarkan Titik Koordinat GPS Menggunakan Smartphone," J. Infomedia, vol. 2, pp. 25-29, 2017.

[5] E. R. Putri, Sistem pakar dengan menggunakan metode dempster shafer untuk mendeteksi jenis perilaku abnormal adhd (attention deficit hyperactivity disorder) pada anak. Pekanbaru: Universitas Islam Negeri Sultan Syarif Kasim Riau, 2013.

[6] R. A. Kusuma, Y. Sholva, and R. D. Nyoto, "Aplikasi Peringatan Rambu Lalu Lintas dengan Metode Location Based Service Berbasis Mobile," J. Sist. dan Teknol. Inf., vol. 08, no. 3, pp. 230-238, 2020.

[7] S. T. Syahputra, "Pendistribusian barang farmasi menggunakan algoritma dijkstra (studi kasus: pt. Air mas chemical)," J. Mantik Penusa, vol. 17, 2015.

[8] D. Ardana and R. Saputra, "Penerapan Algoritma Dijkstra pada Aplikasi Pencarian Rute Bus Trans Semarang," 2016.

[9] Androiddev, "Developer.android." https://developer.android.com/studio/intro?hl=ID.

[10] M. I. Ridwansyah, "Konsep Dasar Database SQLite pada Android," medium.com." https://medium.com/easyread/konsep-dasar-database-sqlitepada-android-e9445558f494.

[11] Firebase, "Firebase Realtime Database." https://firebase.google.com/docs/database?hl=id.

[12] R. A. S and S. M., Rekayasa Perangkat Lunak. Bandung: Informatika, 2018.

[13] W. Gata, Sukses Membangun Aplikasi Penjualan Dengan Java. Jakarta: Elex Media Komputindo, 2013. 